\title{
Surveying Faculty Perspectives on Undergraduate Research, Scholarship, and Creative Activity: A Three-Institution Study
}

\author{
Janet A. Morrison, The College of New Jersey \\ Nancy J. Berner, The University of the South \\ Jill M. Manske, University of St. Thomas \\ Rebecca M. Jones, Shannon N. Davis, Pamela W. Garner, George Mason University
}

\begin{abstract}
The authors surveyed faculty $(n=239)$ at three diverse institutions to probe perceived motivations for and barriers to involvement in undergraduate research, scholarship, and creative activity (URSCA) across scholarly disciplines. URSCA mentors were significantly more likely than nonparticipants to express proficiency in involving students in their research/creative activities, to acknowledge student contributions to their scholarly work, and to state that URSCA mentoring should be considered in personnel decisions. More than half perceived that their institutions did not place sufficient value on mentoring URSCA. Results suggested that institutional URSCA cultures could be enhanced by building mentoring into faculty workload, tenure materials, and promotion documents; using early, course-based research to improve student readiness; providing faculty development on research mentoring aimed at underrepresented disciplines; and seeking novel funding sources targeted at faculty-mentored URSCA.
\end{abstract}

Keywords: creative activity, faculty, mentoring, multiinstitutional survey, undergraduate research

doi: $10.18833 /$ spur/2/1/1

High-impact practices, including undergraduate research, scholarly activity, and creative activity (URSCA), can increase undergraduate retention, graduation rates, and graduate school enrollment. Additionally, students who participate in research activities show improvements in thinking critically and independently, interpreting data, analyzing literature, and presentation skills (Bauer and Bennett 2003; Chopin 2002; Hu et al. 2008; Hunter, Laursen, and Seymour 2007). These intellectual gains are even more pronounced in students who participate in research during their first and second years of college and in traditionally underrepresented students (Girves, Zepeda, and Gwathmey 2005; Kuh 2008; McKinney, Saxe, and Cobb 1998). In response to these documented outcomes, many colleges and universities are investing significant financial and human resources in undergraduate research programs (e.g., Nazaire and Usher 2015; Ramirez et al. 2015). Concurrent with these investments and the associated educational reforms fueling launches of URSCA programs has been the development of a substantial body of academic research on student experiences, perceptions, participation, and outcomes of URSCA. However, far less research has examined faculty members' experiences or their perceptions of and motivators for mentoring undergraduates in these activities (Webber, Laird, and BrckaLorenz 2013). Quantitative research is particularly lacking (Buddie and Collins 2011).

Within this limited but growing body of research on faculty members' perceptions of mentoring URSCA run the common themes that they believe it provides significant educational benefits to students (Gates et al. 1999; Kardash 2000; Zydney et al. 2002) along with significant benefits to their own quality of work and life. For example, faculty members get personal satisfaction from working with students (Adedokun et al. 2010; Cech 2003; Chopin 2002; Hunter et al. 2007; Zydney et al. 2002), it can enhance their professional growth (Chopin 2002; Mateja 
and Otto 2007), and student presentations at research conferences highlight faculty-student work in ways that can enhance visibility of their campus programs (Chapman 2003). Studies that explored faculty mentoring of URSCA have identified a diverse set of motivators, such as the desire to influence the careers of talented young students (Zydney et al. 2002), personal satisfaction, assistance with research tasks, and overarching educational goals and mission (Webber et al. 2013). Some faculty members report that students help them with their research projects by providing additional labor to a project, or by bringing new perspectives to research topics (Cech 2003; Coker and Davies 2006; Zydney et al. 2002).

Although URSCA has laudable benefits for both students and faculty members, it is not without challenges and significant trade-offs for the faculty. Faculty members may value their mentoring relationships with students, but they also may perceive negative effects on their own scholarly work (Buddie and Collins 2011; Mervis 2001). An oft-cited barrier to faculty participation in URSCA is that undergraduate research is too time consuming. In fact, faculty report lack of time as the biggest barrier to mentoring students in URSCA (Brown 2001; Buddie and Collins 2011; Chapman 2003; Coker and Davies 2006; Cooley, Garcia, and Hughes 2008; Hu et al. 2008; Karukstis 2004; Mateja and Otto 2007; McKinney et al. 1998; Perez 2003; Zydney et al. 2002). Another commonly reported barrier is the perception by faculty that students are underprepared for research (Bowman and Stage 2002; Chopin 2002; Coker and Davies 2006; Hu et al. 2008).

Given the important educational outcomes associated with URSCA, more research is needed on the faculty perspective to increase the amount and quality of undergraduate research being conducted at colleges and universities. Little empirical research has examined faculty members' actual experiences supervising undergraduate research, including how many students they supervise, how long they spend with their undergraduate researchers, how the research partnership starts, and what motivates faculty members to engage in mentoring URSCA (Buddie and Collins 2011). The purpose of the present study was to examine the factors that influence faculty members' participation in and perception of URSCA across various institutional contexts and types of scholarly and creative activities. Specifically, the goal was to identify factors that motivate faculty members to participate in URSCA and barriers that exist to participation and to compare these factors in faculty members who did and did not participate in URSCA mentoring.

\section{Methods}

This study was conducted by a multi-institutional research team of faculty and administrators that originated from a research seminar organized and sponsored by the Center for Engaged Learning at Elon University (VandermaasPeeler et al. 2014-2016). Based upon previous work (Jones and Davis 2014), an electronic survey was developed to assess faculty perspectives on faculty-student scholarly and creative activity across different types of institutions and disciplines.

\section{Data Collection}

Using an online platform (SurveyMonkey 2017), the survey instrument was deployed to all faculty at three participating institutions in the United States. Approval from the three surveyed universities' Human Subjects Review Boards was granted for this research. Each institution is described, in brief, below.

The University of St. Thomas (UST) is a private doctoral university. Carrying a moderate research activity Carnegie classification, UST has a total enrollment of approximately 10,000 students and an admissions rate of 86.6 percent. Located in St. Paul, Minnesota, UST also is primarily residential; is majority undergraduate; and offers arts, sciences, and professional education.

Located in Ewing, New Jersey, The College of New Jersey (TCNJ) is a public institution classified as a master's college, with a medium student population (approximately $7,400)$ and very high undergraduate enrollment. This school has arts, sciences, and pre-professional education programs; an admissions rate of 49 percent; and a low transfer rate.

The University of the South (informally known as Sewanee, in Sewanee, Tennessee) is a private, very small institution (enrollment approximately 1,700) with a baccalaureate college classification. It is an institution focused on the arts and sciences, and is highly residential. Sewanee had an admission rate of 64.5 percent at the time of this study (it is now 43 percent) and a very low transfer rate.

\section{Description of Instrument}

The survey instrument built on previously published work (Jones and Davis 2014) on faculty perspectives about undergraduate research. Specifically, the authors surveyed faculty about their perceptions of their influence on how undergraduate students participated in URSCA experiences across diverse institutional contexts. Beyond collecting basic demographic information such as gender, race, and academic discipline, the questionnaire also assessed faculty members' attitudes about and experiences with URSCA. For example, items asked faculty members to provide information about their own research and scholarly activities and to report on the extent to which they included undergraduates in their own research program. Faculty members also were asked about their motivations for and barriers to participating in URSCA. 


\section{Statistical Analysis}

Chi-square tests of independence or Fisher's exact tests were used to compare the frequencies of different responses to a survey question by different categories of respondents. Fisher's test was used when 20 percent or more of expected cell frequencies were less than five (Cochran 1954) for the overall test or in post-hoc pairwise contrasts. The Fisher's test may be somewhat conservative when used with row or column totals that are not fixed, but the loss of power is slight, especially with tables that are larger than two rows by two columns (Ruxton and Neuhäuser 2010). The analyses were done in $\mathrm{R}$ v. 3.3.1, with the crosstable function in the gmodels package and, for contrasts needed to further analyze an overall significant Fisher's test, the pairwiseNominalIndependence function in the rcompanion package ( $\mathrm{R}$ Core Team 2016). Probability values were adjusted with the Bonferroni adjustment for multiple tests. Sample sizes differed for some tests because not all respondents answered every question on the survey. Note that the chi-square test estimates the probability of obtaining the value of the test statistic $\chi^{2}$ by chance alone, whereas the Fisher's exact test directly calculates the probability of getting the observed proportions of the data in each category under the null hypothesis that the proportions are the same; thus, there is no test statistic for the Fisher's exact test.

\section{Results}

\section{Overall Respondent Profile}

The survey was offered to all full-time faculty members at each institution, and the overall response rate was 25 percent. There were a total of 239 responses, with 36.4 percent from TCNJ, 36.0 percent from UST, and 27.6 percent from Sewanee. The responses were pooled across institutions in the analyses presented below in order to have sufficient sample sizes, and because the three institutions were similar in being primarily undergraduate and having strong URSCA cultures. Also, respondents from the three institutions did not vary significantly in the proportion that mentored URSCA (77 percent), tenure status (77 percent tenured), or race (10 percent nonwhite). They differed somewhat in terms of gender and type of scholarly and creative activity, but these differences were not statistically significant (see Table 1). Overall, 53 percent of the respondents were women and 47 percent were men, but somewhat more Sewanee respondents were men (60 percent). Compared to TCNJ and UST, a higher proportion of Sewanee respondents were in the arts and literature, with relatively fewer doing quantitative research (see Figure 1).

\section{Participation in Mentoring URSCA}

Out of the 239 respondents, 77 percent reported that they had participated in mentoring URSCA. Most of these (47.5 percent) usually had one or more students per semester. Fewer (29.8 percent) mentored less than one student per year. Of those who had not participated, 15 percent responded that they wanted to participate, 6 percent expressed no interest, and 1.5 percent reported that they did not engage in scholarly or creative activity. The only significant difference in demographic characteristics between participants and nonparticipants was the type of scholarly or creative activity they did (see Table 2). Participants were most likely to be those who used purely quantitative methods or multimethods that included quantitative methods, and the lowest participation rate was for respondents who did nonempirical research. This difference was statistically significant (see Figure 2). Women and men, white and nonwhite, and tenured and tenure-track respondents participated at similar rates (see Table 2).

TABLE 1. Chi-Square Tests of Independence that Compare Respondents from The College of New Jersey, University of St. Thomas, and The University of the South in Terms of Selected Demographic and Academic Characteristics

\begin{tabular}{|l|c|c|c|c|l|}
\hline $\begin{array}{l}\text { Descriptor } \\
\text { (sample size) }\end{array}$ & $\chi^{2}$ & df & $\mathrm{P}$ & $\begin{array}{l}\text { Significance } \\
\text { level }^{\mathbf{a}}\end{array}$ & $\begin{array}{l}\text { Percentages of respondents } \\
\text { across all three institutions }\end{array}$ \\
\hline $\begin{array}{l}\text { Engage in } \\
\begin{array}{l}\text { URSCA } \\
(239)\end{array}\end{array}$ & 3.70 & 2 & 0.16 & $\mathrm{~ns}$ & Yes $=77 \%$; No $=23 \%$ \\
\hline $\begin{array}{l}\text { Research type } \\
(234)\end{array}$ & 15.03 & 8 & 0.06 & $\mathrm{~ns}$ & See Figure 1 \\
\hline $\begin{array}{l}\text { Gender } \\
(234)\end{array}$ & 5.79 & 2 & 0.06 & $\mathrm{~ns}$ & $\begin{array}{l}\text { Women }=53 \% \text {;en }=47 \% \\
\text { (The University of the South: } 60 \% \text { men })\end{array}$ \\
\hline $\begin{array}{l}\text { Race } \\
(224)\end{array}$ & 1.95 & 2 & 0.38 & $\mathrm{~ns}$ & White $=90 \%$; Nonwhite $=10 \%$ \\
\hline $\begin{array}{l}\text { Tenure } \\
(225)\end{array}$ & 0.62 & 2 & 0.73 & $\mathrm{~ns}$ & Tenured $=77 \%$; Untenured $=23 \%$ \\
\hline
\end{tabular}

Note: ${ }^{a}$ Bonferroni adjustment for five tests; $\mathrm{P}=0.01$ for significance at the 0.05 level; $\mathrm{ns}=$ not significant 
FIGURE 1. Type of Scholarly/Creative Activity of Faculty Survey Respondents at Three Institutions

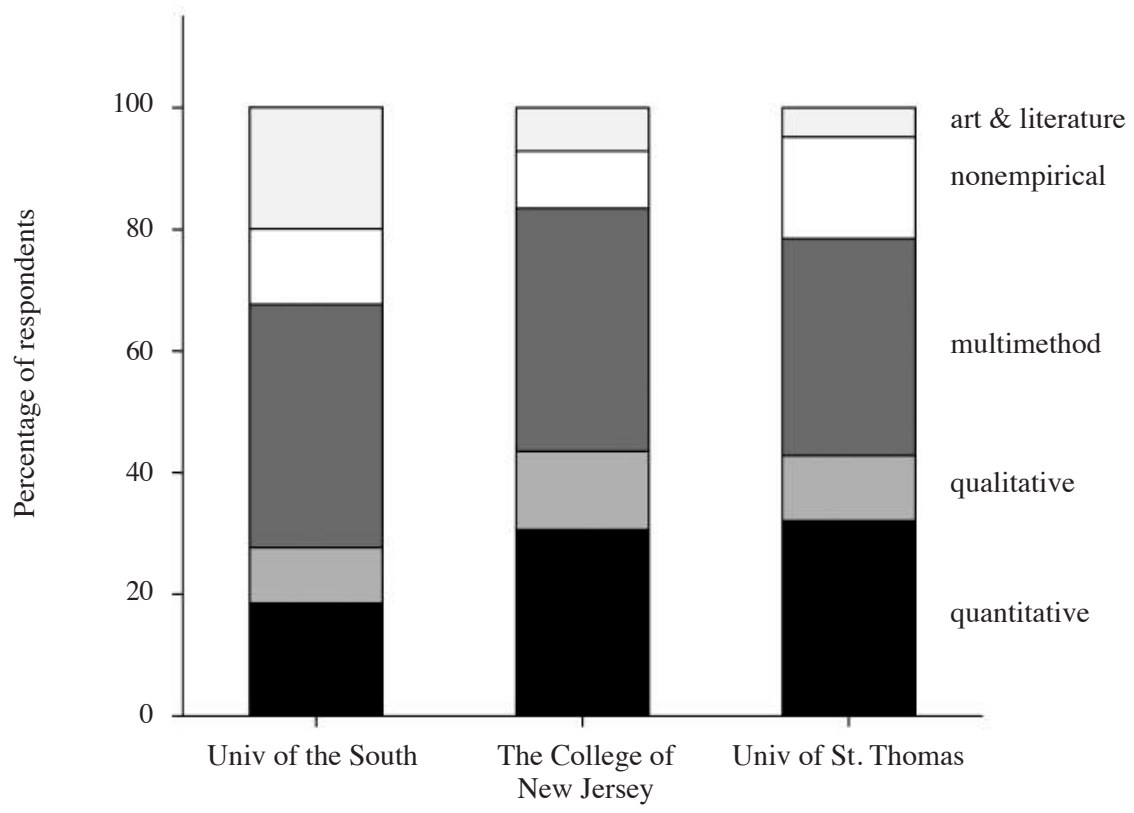

TABLE 2. Chi-Square Tests of Independence or Fisher Exact Tests (FET) That Compare Categories within Selected Demographic and Academic Characteristics for Their Frequencies of Participation or Nonparticipation in Mentoring URSCA

\begin{tabular}{|l|c|c|c|c|l|}
\hline $\begin{array}{l}\text { Respondent } \\
\text { characteristic } \\
\text { (sample size) }\end{array}$ & $\chi^{2}$ & df & $\mathrm{P}$ & $\begin{array}{c}\text { Significance } \\
\text { level }^{\mathrm{a}}\end{array}$ & Frequencies of participation \\
\hline $\begin{array}{l}\text { Research type } \\
(234)\end{array}$ & $\begin{array}{c}\mathrm{n} / \mathrm{a} \\
(\mathrm{FET})\end{array}$ & 4 & $3.86 \times 10^{-5}$ & $* * *$ & See Figure 2 \\
\hline $\begin{array}{l}\text { Gender } \\
(234)\end{array}$ & 0.02 & 1 & 0.89 & $\mathrm{~ns}$ & Female $=77.4 \%$; Male $=78.2 \%$ \\
\hline $\begin{array}{l}\text { Race } \\
(224)\end{array}$ & $\mathrm{n} / \mathrm{a}$ & 1 & 0.28 & $\mathrm{~ns}$ & Nonwhite $=68.2 \%$; White $=78.7 \%$ \\
\hline $\begin{array}{l}\text { Tenure } \\
(225)\end{array}$ & 0.06 & 1 & 0.80 & $\mathrm{~ns}$ & $\begin{array}{l}\text { Tenured }=79.2 \% \text {; Tenure-track }= \\
0.8 \%\end{array}$ \\
\hline
\end{tabular}


$* * * \mathrm{P}<0.001$

\section{Perspectives on Mentoring URSCA:}

Participants versus Nonparticipants

Respondents who had participated in mentoring differed significantly from nonparticipants in three key perspectives about URSCA (see Table 3). A significantly greater percentage of participants than nonparticipants agreed with the survey statements that said they knew how to involve undergraduates in their research and that mentoring URSCA should be considered in personnel decisions like tenure and promotion. A significantly smaller percentage of participants than nonparticipants agreed with the survey statement that undergraduates could not contribute to faculty research. Participants and nonparticipants did not differ significantly in other perspectives on URSCA. Both groups enjoyed their scholarly/creative activity, and a majority of respondents in each group agreed with the statement that they conducted research primarily for themselves, although a large minority in each group agreed with the statement that they did it primarily for students. Finally, close to half of participants and nonparticipants agreed with the survey statement that they did not receive enough credit for their work with undergraduate students.

\section{Perceived Barriers to Mentoring URSCA: Participants versus Nonparticipants}

All respondents were asked to rate the importance to them of six potential barriers to their engagement in URSCA. 
FIGURE 2. Percentage of Respondents Who Have Mentored URSCA by Type of Research/Creative Activity

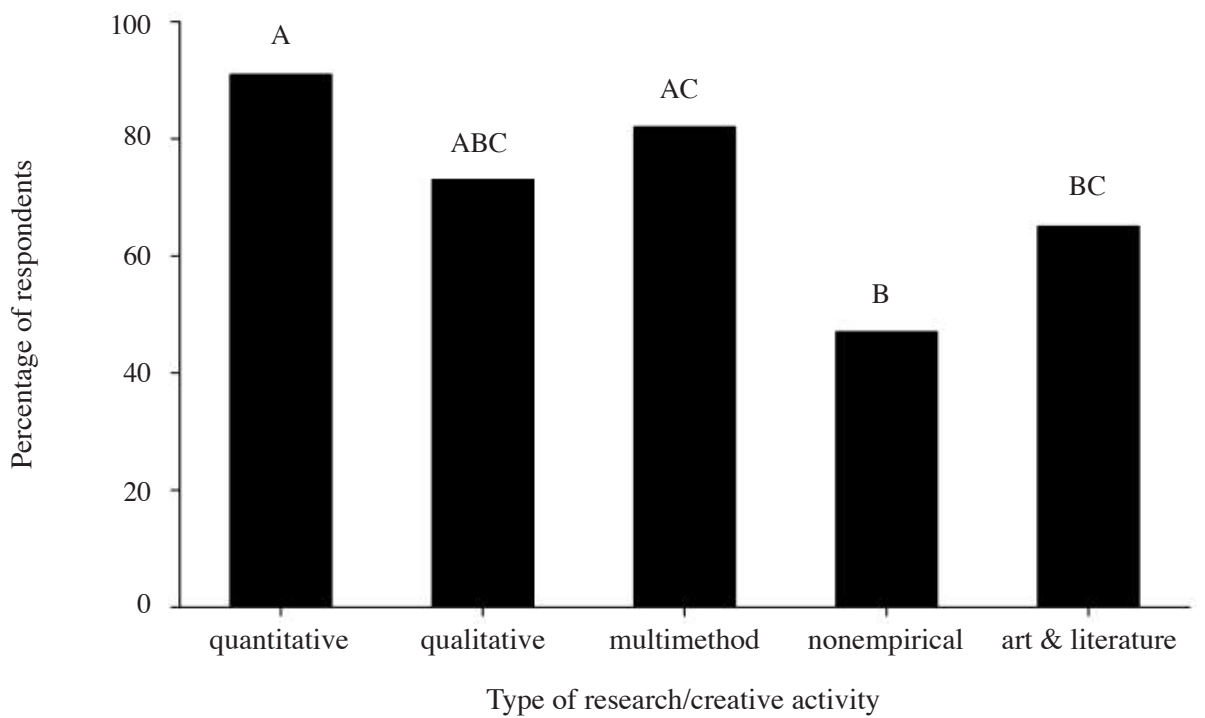

Note: Bars with labels that include the same letter were not significantly different based on post-hoc pairwise Fisher exact tests.

Options were "very significant," "a lot," "moderate," "minimal," or "not significant." There were no significant differences of opinion between those who mentored URSCA and those who did not for any of the identified barriers (see Table 4). They thought that lack of time was the most important, followed by lack of funding and "students not prepared." Less important were lack of departmental support and not receiving credit toward personnel actions. Most respondents did not think that lack of students was a barrier. Respondents who had not mentored URSCA were nearly twice as likely to think that students were "not prepared to engage in these activities," although the $\chi^{2}$ for that barrier was not significant after the Bonferroni correction for multiple tests, which is a conservative method.

\section{Ranking of Perceived Barriers by Nonparticipants}

The survey asked only those respondents who indicated that they had not participated in mentoring URSCA ( $n=$ 49) to rank by importance the six potential barriers. The most important obstacle in the ranking was lack of time followed by "students are not prepared for research." The least important obstacles were lack of access to undergraduate students and lack of departmental support. Not receiving credit toward personnel actions ranked as the fourth most important obstacle and the third was lack of funding (see Table 5).

\section{Participants' Motivators}

The respondents who reported that they had mentored students in URSCA $(n=185)$ were asked a series of questions to probe their motivations for doing so. High percentages of the respondents agreed or strongly agreed with all of the motivators that were included. The motivator that had the highest rating was "it is good for students," followed by caring about future generations of scholars and enjoying it. The lowest rated motivators were "to advance my own research" and because graduate students were not available (see Table 6). The authors explored more fully the responses to the "advance my own research" motivator to learn if the responses differed by type of research. For this chi-square test, the neutral, disagree, and strongly disagree categories were collapsed into one category of "do not agree." The distribution of responses for those who did nonempirical research was very skewed toward "do not agree" when compared to the other research types $\left(\chi^{2}=\right.$ 17.68; $p=0.02 ; \mathrm{df}=8$ ). This result should be interpreted with some caution, however, because 27 percent of the expected cell frequencies were less than five, so the $\chi^{2}$ test might not be valid. One cell had an observed value equal to zero, so the Fisher's exact test could not be used. However, when the respondents who did nonempirical research were removed, there were no longer differences among research types $\left(\chi^{2}=2.34 ; p=0.89 ; \mathrm{df}=6\right)$ (see Figure 3 ).

\section{Discussion and Conclusions}

This study was undertaken to determine the factors that influence faculty members' participation in URSCA across various institutional contexts, scholarly disciplines, gender, race, and tenure status, in order to identify strategies that may enhance the quantity and quality of URSCA mentoring. The data suggest several ways by which institutions that want to promote URSCA may encourage participation by their faculties. Because there were no differences in 
TABLE 3. Chi-Square Tests of Independence or Fisher Exact Tests (FET) That Compare Respondents Who Did or Did Not Participate in Mentoring, in Terms of Perspectives on Research and URSCA

\begin{tabular}{|c|c|c|c|c|c|c|}
\hline \multirow[b]{2}{*}{$\begin{array}{l}\text { Perspective } \\
\text { (sample size) }\end{array}$} & \multirow[b]{2}{*}{$\chi^{2}$} & \multirow[b]{2}{*}{$\mathrm{df}$} & \multirow[b]{2}{*}{$\mathrm{P}$} & \multirow[b]{2}{*}{$\begin{array}{c}\text { Significance } \\
\text { level }^{\mathrm{a}}\end{array}$} & \multicolumn{2}{|c|}{$\begin{array}{l}\text { Percentage responding } \\
\text { "strongly agree" / "agree" }\end{array}$} \\
\hline & & & & & Participants & Nonparticipants \\
\hline $\begin{array}{l}\text { I enjoy scholarly and } \\
\text { creative activity. (238) }\end{array}$ & $\begin{array}{c}\mathrm{n} / \mathrm{a} \\
(\mathrm{FET})\end{array}$ & 4 & 0.06 & ns & $96 \%$ & $85 \%$ \\
\hline $\begin{array}{l}\text { I primarily conduct } \\
\text { research for myself. } \\
(232)\end{array}$ & 6.43 & 4 & 0.17 & ns & $54 \%$ & $68 \%$ \\
\hline $\begin{array}{l}\text { The main reason I } \\
\text { conduct research is for } \\
\text { the benefit of my } \\
\text { students. (234) }\end{array}$ & $\begin{array}{c}\mathrm{n} / \mathrm{a} \\
(\mathrm{FET})\end{array}$ & 4 & 0.20 & ns & $37 \%$ & $27 \%$ \\
\hline $\begin{array}{l}\text { The costs of conduct- } \\
\text { ing research outweigh } \\
\text { the benefits. }(233)\end{array}$ & 7.47 & 4 & 0.11 & ns & $21 \%$ & $17 \%$ \\
\hline $\begin{array}{l}\text { I know how to involve } \\
\text { undergraduates in } \\
\text { scholarly and creative } \\
\text { activity. (234) }\end{array}$ & $\begin{array}{c}\mathrm{n} / \mathrm{a} \\
(\mathrm{FET})\end{array}$ & 4 & $2.1 \times 10^{-10}$ & $* * * *$ & $85 \%$ & $43 \%$ \\
\hline $\begin{array}{l}\text { An undergraduate stu- } \\
\text { dent cannot contribute } \\
\text { to my research. }(231)\end{array}$ & $\begin{array}{c}\mathrm{n} / \mathrm{a} \\
(\mathrm{FET})\end{array}$ & 4 & $5.2 \times 10^{-10}$ & $* * * *$ & $7 \%$ & $28 \%$ \\
\hline $\begin{array}{l}\text { Research involving } \\
\text { undergraduates should } \\
\text { be considered in } \\
\text { personnel actions (e.g., } \\
\text { promotion, tenure). } \\
\text { (231) }\end{array}$ & $\begin{array}{c}\mathrm{n} / \mathrm{a} \\
(\mathrm{FET})\end{array}$ & 4 & $1.2 \times 10^{-6}$ & $* * * *$ & $85 \%$ & $56 \%$ \\
\hline $\begin{array}{l}\text { I do not receive enough } \\
\text { credit for my work } \\
\text { with undergraduates. } \\
\text { (221) }\end{array}$ & 1.75 & 4 & 0.78 & ns & $49 \%$ & $44 \%$ \\
\hline
\end{tabular}

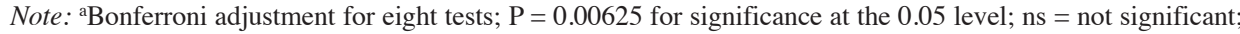
$* * * * \mathrm{P}<0.0001$

gender, race, or tenure status with regard to those faculty members who participated and those who did not, these strategies are not targeted to particular faculty demographic groups. The three institutions in the survey differed little in their faculties' responses, even though the institutions were diverse in some respects (e.g., size, private or public). Notably, however, they were similar in being strongly undergraduate-focused, with developed URSCA cultures. There were only three institutions in the study. It would be of great interest to deploy this survey more widely, including at larger research universities, which also would allow consideration of the connection between undergraduate and graduate student mentoring.

There are five significant lessons learned from this study. First, as in previous studies (e.g., Baker et al. 2015; Jones and Davis 2014), most faculty members who responded to the survey, regardless of whether or not they participated in URSCA, perceived lack of time as a significant barrier to their participation. Institutions should find ways to relieve this time burden by finding ways to credit URSCA in overall faculty workloads. The three institutions in this study have all addressed this need with a variety of approaches. For example, at TCNJ faculty members earn in-load teaching credit for an aggregated number of undergraduate research credits earned by the students (Osborn and Morrison 2008; Paul 2004). Most faculty mentors at Sewanee have students work in pairs or groups, which helps the students and also decreases the amount of time it takes to work with them. Course-reassignment is provided at UST for one course per semester to all tenure-track and tenured faculty in the laboratory sciences, in recognition of the unique and additional time requirements inherent in doing experimental laboratory 
TABLE 4. Chi-Square Tests of Independence or Fisher Exact Tests (FET) That Compare Respondents Who Did and Did Not Participate in Mentoring URSCA, in Terms of Their Perceptions of the Importance of Potential Barriers

\begin{tabular}{|c|c|c|c|c|c|c|}
\hline \multirow{2}{*}{$\begin{array}{l}\text { Barriers- } \\
\text { importance of: } \\
\text { (sample size) }\end{array}$} & \multirow[b]{2}{*}{$\chi^{2}$} & \multirow[b]{2}{*}{$d f$} & \multirow[b]{2}{*}{$P$} & \multirow[b]{2}{*}{$\begin{array}{c}\text { Significance } \\
\text { level }^{\mathrm{a}}\end{array}$} & \multicolumn{2}{|c|}{$\begin{array}{l}\text { Percentage responding } \\
\text { "very significant" or "a lot" }\end{array}$} \\
\hline & & & & & Participants & Nonparticipants \\
\hline $\begin{array}{l}\text { Lack of access to } \\
\text { undergraduate students } \\
(234)\end{array}$ & $\begin{array}{c}\mathrm{n} / \mathrm{a} \\
(\mathrm{FET})\end{array}$ & 4 & 0.07 & ns & $6 \%$ & $12 \%$ \\
\hline $\begin{array}{l}\text { Students are not } \\
\text { prepared for research } \\
(236)\end{array}$ & 11.15 & 4 & 0.03 & ns & $37 \%$ & $61 \%$ \\
\hline Lack of time (238) & $\begin{array}{c}\mathrm{n} / \mathrm{a} \\
(\mathrm{FET})\end{array}$ & 4 & 0.39 & ns & $63 \%$ & $72 \%$ \\
\hline Lack of funding (236) & 2.78 & 4 & 0.60 & ns & $31 \%$ & $43 \%$ \\
\hline $\begin{array}{l}\text { Not receiving credit } \\
\text { toward personnel } \\
\text { actions }(226)\end{array}$ & 6.03 & 4 & 0.20 & ns & $31 \%$ & $32 \%$ \\
\hline $\begin{array}{l}\text { Lack of department } \\
\text { support }(229)\end{array}$ & $\begin{array}{c}\mathrm{n} / \mathrm{a} \\
(\mathrm{FET})\end{array}$ & 4 & 0.18 & ns & $13 \%$ & $24 \%$ \\
\hline
\end{tabular}

Note: ${ }^{a}$ Bonferroni adjustment for six tests; $\mathrm{P}=0.008$ for significance at the 0.05 level; $\mathrm{ns}=$ not significant

TABLE 5. Ranking of the Importance of Six Potential Barriers to Mentoring URSCA as Perceived by Respondents Who Have Not Participated in Mentoring $(n=49)$

\begin{tabular}{|c|c|c|c|c|c|c|}
\hline \multirow[b]{2}{*}{ Barrier rank (1 = most important) } & \multicolumn{6}{|c|}{ Number of respondents assigning the rank } \\
\hline & 1 & 2 & 3 & 4 & 5 & 6 \\
\hline $\begin{array}{l}\text { Lack of access to undergraduate } \\
\text { students }\end{array}$ & 1 & 3 & 3 & 6 & 11 & 25 \\
\hline $\begin{array}{l}\text { Students are not prepared for } \\
\text { research }\end{array}$ & 20 & 15 & 5 & 3 & 4 & 2 \\
\hline Lack of time & 23 & 15 & 6 & 3 & 2 & 0 \\
\hline Lack of funding & 4 & 13 & 18 & 5 & 7 & 2 \\
\hline $\begin{array}{l}\text { No credit toward personnel } \\
\text { actions }\end{array}$ & 1 & 3 & 9 & 20 & 9 & 7 \\
\hline Lack of department support & 0 & 0 & 8 & 12 & 16 & 13 \\
\hline
\end{tabular}

research with undergraduates. These approaches can be adopted as best practices at many more institutions.

Second, also congruent with other studies, many nonparticipants attributed their lack of participation to student factors, such as "students are not prepared for research" and "an undergraduate student cannot contribute to my research." In fact, students who want to participate in undergraduate research but have not yet done so feel that they lack readiness (Jones et al. 2016). Another related perception among nonparticipant faculty members was that they did not know how to involve undergraduates in scholarly and creative activity. In the case of students without the background necessary to participate in URSCA, institutions can encourage academic departments to embed research into existing courses or design comprehensive undergraduate research and creative experience models (Awong-Taylor et al. 2016; Davis and Jacobsen 2014). Indeed, all three of the 
TABLE 6. Percentage of Agree and Disagree Responses by URSCA Mentors to Statements about What Motivates Them to Engage Undergraduates in Scholarly and Creative Activity ( $n=182-184$ respondents)

\begin{tabular}{|l|c|c|}
\hline Motivator & Strongly agree / agree & $\begin{array}{c}\text { Strongly disagree / } \\
\text { disagree }\end{array}$ \\
\hline It is good for the student & $97 \%$ & $0.5 \%$ \\
\hline I care about the future generation of scholars & $87 \%$ & $1 \%$ \\
\hline I enjoy it & $86 \%$ & $1 \%$ \\
\hline It helps me feel better about my job & $77 \%$ & $3 \%$ \\
\hline To advance my own research & $68 \%$ & $2 \%$ \\
\hline $\begin{array}{l}\text { There are no graduate students to help with } \\
\text { my work }\end{array}$ & $64 \%$ & $22 \%$ \\
\hline
\end{tabular}



FIGURE 3. Responses by Faculty URSCA Mentors with Different Types of Research/Creative Activity to the Statement that a Motivation for Mentoring URSCA Is That It Can "Advance My Own Research"

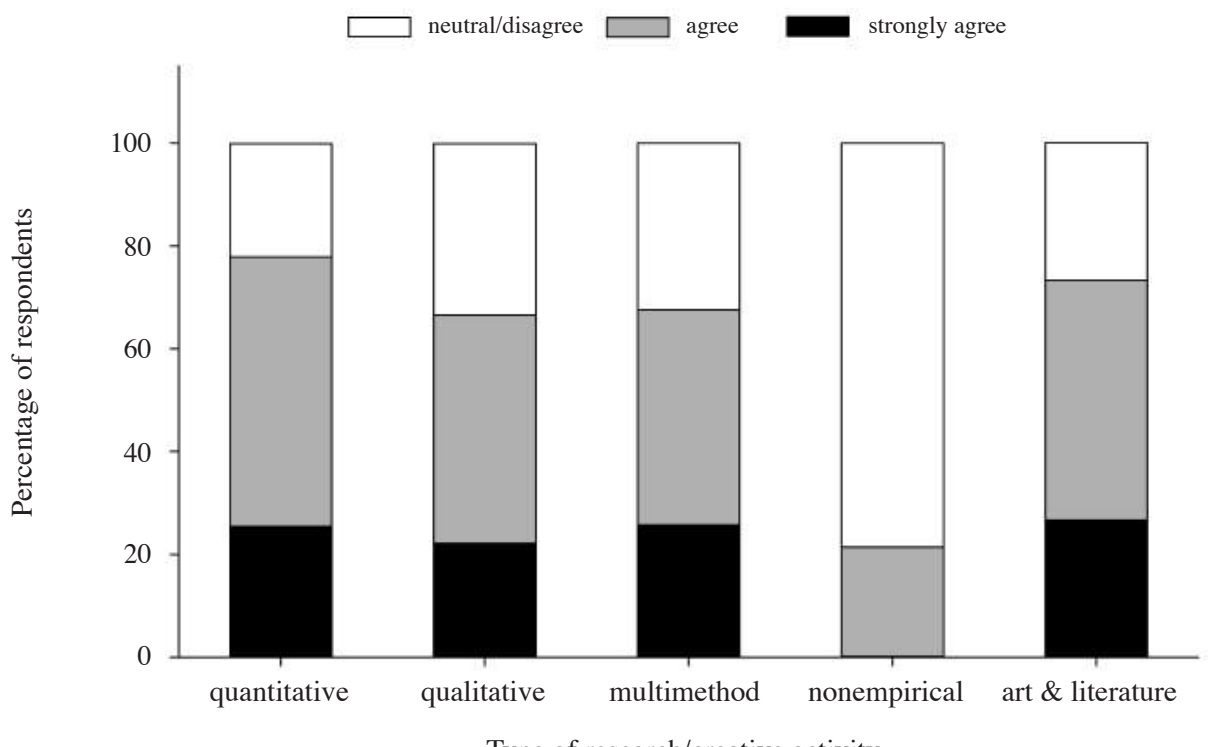

Type of research/creative activity

institutions included here have effective examples of early exposure to research, from a summer program for incoming first-year students at Sewanee to first- and second-year research-based courses at UST (Chaplin, Manske, and Cruise 1998) and TCNJ. In addition, institutional offices for undergraduate research or centers for teaching can sponsor workshops or discussion groups in which faculty experienced in URSCA can mentor nonparticipating faculty members (a "mentor the mentor" program). Research shows that the quality and quantity of mentorship is critical to the success of URSCA (Jones and Davis 2017; Shanahan et al. 2015). These studies, along with workshops available through the National Research Mentoring Network (https:// nrmnet.net), can provide a basis for programs to train both faculty and peer student mentors.

Third, among faculty participants, lack of funding was seen as a significant barrier. Student researchers are more likely than their faculty counterparts to need to repeat research work to correct methodological errors. In some 
disciplines in which experiments depend upon expensive disposable chemicals and supplies, for example, this can result in higher costs for collecting the same data. Institutions can relieve this cost barrier with funds specifically targeted for undergraduate researchers. At UST, for example, federal student work-study can be used to fund student research collaborators, a practice used by some other institutions as well, such as George Mason University (Nazaire and Usher 2015). Both TCNJ and UST have built research funds into their annual science department budgets, providing a dependable, if modest, source of revenue for faculty-student research. Institutions also can seek external funding from sources that fund undergraduate education; for example, the National Science Foundation and the Jessie Ball duPont Foundation fund Sewanee's summer program. Ramirez and colleagues (2015) suggest several nontraditional sources of funding, such as industry partners, event-based partnerships, and contracted research and service learning opportunities, like those developed at Loyola Marymount University.

Fourth, although most faculty did not rank "not receiving credit toward personnel actions" as a highly important barrier to their participation in URSCA, most agreed that it should be considered for tenure and promotion actions, and almost half agreed that they did not receive enough credit for working with undergraduates. The "credit" can be interpreted as credit in their teaching load or credit with regard to personnel actions and prizes. Institutions can add language to their faculty handbooks or other faculty evaluation guidelines that clearly articulates their priority for faculty involvement in URSCA. At TCNJ, for example, this language is present in the college-wide tenure and promotion document, with more specific language in many departments' written standards for scholarly work. At the institutional level, this process will be facilitated by having full agreement within the faculty about counting URSCA mentoring for tenure and promotion. This study's data showed that nonparticipants were significantly less likely to agree that it should be counted, so increasing the participation rate is an important step toward the faculty gaining credit for URSCA mentoring.

Finally, it was found that faculty members who participated in nonempirical research did not agree that advancing their own research was a motivator for participating in URSCA, and a lower fraction of these faculty members participated in URSCA. Conventional wisdom says that collaborative research in the arts and humanities is difficult to impossible. However, in 2008 the Council on Undergraduate Research supported undergraduate research in the arts and humanities with the addition of a Division of Arts and Humanities, and a host of supporting programs (Council on Undergraduate Research 2018), and several schools offer models worth investigating, such as the Albright Creative Research Experience (ACRE) at Albright College
(Albright College 2018; Gilliams et al. 2008). At TCNJ, specific efforts have been made to nurture participation by arts and humanities faculty-student teams during the Mentored Undergraduate Summer Experience (an internally funded eight-week residential program), and there have been many successful projects in the visual arts, music, film, and the humanities.

Faculty mentoring of undergraduate research and creative activity that is widespread across many disciplines and contributes to faculty scholarship is essential for building an institutional culture that values and supports this high-impact practice. Its benefits for students is clear, so it remains for it to more broadly benefit the mentors. The strategies suggested by the data of this study - building URSCA mentoring into faculty workload and tenure and promotion guidelines, improving students' research readiness with course-based research, offering faculty development in research mentoring in all disciplines, and seeking creative sources of dedicated funding - will all contribute to an institutional culture that fully supports this essential form of faculty-student engagement.

\section{Acknowledgments}

The authors thank the organizers of the Center for Engaged Learning's Research Seminar on Excellence in Mentoring Undergraduate Research at Elon University for support during the development and implementation of this study. The authors also thank Duhita Mahatmya and Ann Johnson, two other colleagues from the seminar, for their contributions to the team and comments on this manuscript. Further information about the instrument discussed in this article may be obtained from Rebecca Jones (rjones22@ gmu.edu).

\section{References}

Adedokun, Omolola, Melissa Dyehouse, Ann Bessenbacher, and Wilella Burgess. 2010. "Exploring Faculty Perception of the Benefits and Challenges of Mentoring Undergraduate Research Students." Poster presented at the Annual Meeting of the American Educational Research Association, Denver, CO.

Albright College. "Experiential Learning \& Career Development Center." Accessed July 17, 2018. https://www.albright.edu/ about-albright/offices-departments/elcde/

Awong-Taylor, Judy, Allison D'Costa, Greta Giles, Tirza Leader, David Pursell, Clay Runck, and Thomas Mundie. 2016. "Undergraduate Research for All: Addressing the Elephant in the Room." CUR Quarterly 37(1): 11-19. doi: 10.18833/curq/37/1/4

Baker, Vicki L., Meghan J. Pifer, Laura G. Lunsford, Jane Greer, and Dijana Ihas. 2015. "Faculty as Mentors in Undergraduate Research, Scholarship, and Creative Work: Motivating and Inhibiting Factors." Mentoring and Tutoring: Partnership in Learning 23: 394-410. doi: 10.1080/13611267.2015.1126164

Bauer, Karen W., and Joan S. Bennett. 2003. "Alumni Perceptions Used to Assess Undergraduate Research Experience.” Journal of Higher Education 74: 210-230. doi:10.1353/jhe.2003.0011 
Bowman, Martha H., and Frances K. Stage. 2002. "Personalizing the Goals of Undergraduate Research." Journal of College Science Teaching 32(2): 120-125.

Brown, Kathryn. 2001. “Time, Money, Mentors.” HHMI Bulletin 14: 30-33.

Buddie, Amy M., and Courtney L. Collins. 2011. "Faculty Perceptions of Undergraduate Research." PURM: Perspectives on Undergraduate Research and Mentoring. https://blogs.elon. edu/purm/2011/10/11/faculty-perceptions-of-undergraduateresearch-purm-1-1

Cech, Thomas R. 2003. "Rebalancing Teaching and Research." Science 299: 165. doi: 10.1126/science.299.5604.165

Chaplin, Susan B., Jill M. Manske, and Jennifer L. Cruise. 1998. "Introducing Freshmen to Investigative Research - A Course for Biology Majors at Minnesota's University of St. Thomas: How 'Investigative Labs' Change the Student from Passive DirectionFollower to Analytically Critical Thinker." Journal of College Science Teaching 27(5): 347-350.

Chapman, David W. 2003. "Undergraduate Research: Showcasing Young Scholars." Chronicle of Higher Education. https:// www.chronicle.com/article/Undergraduate-Research-/9284

Chopin, Suzzette F. 2002. "Undergraduate Research Experiences: The Translation of Science Education from Reading to Doing." Anatomical Record 269: 3-10. doi:10.1002/ar.10058

Cochran, William G. 1954. "Some Methods for Strengthening the Common Chi-Squared Tests." Biometrics 10:417-451. doi: $10.2307 / 3001616$

Coker, Jeffrey S., and Eric Davies. 2006. "Ten Time-Saving Tips for Undergraduate Research Mentors." Journal of Natural Resources \& Life Sciences Education 35: 110-112. doi:10.2134/ jnrlse2006.110s

Cooley, Eileen L., Amber L. Garcia, and Jennifer L. Hughes. 2008. "Undergraduate Research in Psychology at Liberal Arts Colleges: Reflections on Mutual Benefits for Faculty and Students." North American Journal of Psychology 10: 463-472.

Council on Undergraduate Research. "Arts and Humanities." Accessed July 17, 2018. https://www.cur.org/governance/divisions/arts_and_humanities

Davis, Shannon N., and Shannon K. Jacobsen. 2014. "Curricular Integration as Innovation: Faculty Insights on Barriers to Institutionalizing Change." Innovative Higher Education 39: 17-31. doi:10.1007/s10755-013-9254-3

Gates, Ann Q., Patricia J. Teller, Andrew Bernat, Nelly Delgado, and Connie K. Della-Piana. 1999. "Expanding Participation in Undergraduate Research Using the Affinity Group Model." Journal of Engineering Education 88: 409-414. doi:10.1002/j.2168-9830.1999.tb00467.x

Gilliams, Teresa, Lawrence Morris, Kristen Woodward, Kennon Rice, and David Osgood. 2008. "Models and Assessment of Collaborative Research in the Arts and Humanities." CUR Quarterly 29(2): 34-37.

Girves, Jean E., Yolanda Zepeda, and Judith K. Gwathmey. 2005. "Mentoring in a Post-Affirmative Action World."

52 Scholarship and Practice of Undergraduate Research
Journal of Social Issues 61: 449-479. doi:10.1111/j.15404560.2005.00416.x

Hu, Shouping, Kathyrine L. Scheuch, Robert Schwartz, Joy Gaston Gayles, and Shaoqing Li. 2008. "Reinventing Undergraduate Education: Engaging College Students in Research and Creative Activities." ASHE Higher Education Report 33(4). doi:10.1002/ aehe.3304

Hunter, Anne-Barrie, Sandra L. Laursen, and Elaine Seymour. 2007. "Becoming a Scientist: The Role of Undergraduate Research in Students' Cognitive, Personal, and Professional Development." Science Education 91: 36-74. doi: 10.1002/ sce. 20173

Jones, Rebecca M., and Shannon N. Davis. 2014. "Assessing Faculty Perspectives on Undergraduate Research: Implications from Studies of Two Faculties." CUR Quarterly 34(4): 37-42.

Jones, Rebecca M., and Shannon N. Davis. 2017. "Understanding the Role of the Mentor in Developing Research Competency among Undergraduate Researchers." Mentoring and Tutoring: Partnership in Learning 25 (455-465).

Jones, Rebecca M., Janet A. Morrison, Duhita Mahatmya, Nancy Berner, Shannon N. Davis, Jayna L. Ditty, Pamela W. Garner, Ann Johnson, and Jill M. Manske. 2016. "Pathways to and through Undergraduate Research: A Multi-Institutional Assessment." Poster presented at the Council on Undergraduate Research Biennial Conference, Tampa, FL.

Kardash, CarolAnne M. 2000. "Evaluation of Undergraduate Research Experience: Perceptions of Undergraduate Interns and Their Faculty Mentors." Journal of Educational Psychology 92: 191-201. doi:10.1037//0022-0663.92.1.191

Karukstis, Kerry K. 2004. "Creating Time for Research: Recommendations from Faculty at Predominantly Undergraduate Institutions." Journal of Chemical Education 81: 1550. doi:10.1021/ ed081p1550

Kuh, George. 2008. High-Impact Educational Practices: What They Are, Who Has Access to Them, and Why They Matter. Washington, DC: Association of American Colleges and Universities.

Mateja, John, and Charlotte Otto. 2007. "Undergraduate Research: Approaches to Success." In Invention and Impact: Building Excellence in Undergraduate Science, Technology, Engineering and Mathematics (STEM) Education, 269-272. Washington, DC: American Association for the Advancement of Science. https:// www.aaas.org/sites/default/files/09_Prep_Grad_Mateja.pdf

McKinney, Kathleen, David Saxe, and Laura Cobb. 1998. "Are We Really Doing All We Can for Our Undergraduates? Professional Socialization via Out-of-Class Experiences." Teaching Sociology 26: 1-13. doi:10.2307/1318675

Mervis, Jeffrey. 2001. "Student Research: What Is It Good for?" Science 293: 1614-1615. doi:10.1126/science.293.5535.1614

Nazaire, D. W., and B. M. Usher. 2015. "Leveraging Federal Work-Study to Support Undergraduate Research." CUR Quarterly 36(2): 9-17.

Osborn, Jeffrey M., and Janet A. Morrison. 2008. "Shifting an Institutional Infrastructure and Culture to Promote and Support 
Faculty-Student Collaborative Research." Presentation at AAC\&U Academic Network Meeting on Engaging Science, Advancing Learning: General Education, Majors, and the New Global Century, Providence, RI.

Paul, Elizabeth L. 2004. "Creating More Time for Research through Institutional Change." CUR Quarterly 24(4): 178.

Perez, Jorge A. 2003. "Undergraduate Research at Two-Year Colleges." New Directions for Teaching and Learning 93: 69-78. doi:10.1002/tl.89

Ramirez, Martina, Joseph McNicholas, Brianne Gilbert, José Saez, and Matthew Siniawski. 2015. "Creative Funding Strategies for Undergraduate Research at a Primarily Undergraduate Liberal Arts Institution." CUR Quarterly 36(2): 5-8. doi:10.18833/ curq/36/2/1.

R Core Team. 2016. "R: A Language and Environment for Statistical Computing." Accessed November 18, 2016. Vienna, Austria: R Foundation for Statistical Computing. http://www.R-project.org

Ruxton, Graeme D., and Markus Neuhäuser. 2010. "Good Practice in Testing for an Association in Contingency Tables." Behavioral Ecology and Sociobiology 64: 1501-1513. doi: 10.1007/ s00265-010-1014-0

Shanahan, Jenny Olin, Elizabeth Ackley-Holbrook, Eric Hall, Kearsley Stewart, and Helen Walkington. 2015. "Ten Salient Practices of Undergraduate Research Mentors: A Review of the Literature." Mentoring \& Tutoring: Partnership in Learning 23: 359-376. doi:10.1080/13611267.2015.1126162

SurveyMonkey. Retrieved February 28, 2017. https://www.surveymonkey.com

Vandermaas-Peeler, Maureen, Paul Miller, W. Brad Johnson, and Laura L. Behling. 2014-2016. Center for Engaged Learning Seminar on Excellence in Mentoring Undergraduate Research, Elon University, Elon, NC. http://www.centerforengagedlearning.org/mentoringur

Webber, Karen L., Thomas F. Nelson Laird, and Allison M. BrckaLorenz. 2013. "Student and Faculty Member Engagement in Undergraduate Research." Research in Higher Education 54: 227-249. doi:10.1007/s11162-012-9280-5

Zydney, Andrew L., Joan S. Bennett, Abdus Shahid, and Karen W. Bauer. 2002. "Impact of Undergraduate Research Experience in Engineering." Journal of Engineering Education 91: 151-157. doi:10.1002/j.2168-9830.2002.tb00687.x

\section{Janet A Morrison}

The College of New Jersey, morrisja@tcnj.edu

Janet A. Morrison, professor of biology at TCNJ, held the inaugural Barbara Meyers Pelson '59 Chair in FacultyStudent Engagement (2015-2018) and is a former department chair. She was founding director of faculty-student scholarly and creative collaborative activity at TCNJ and was its first director of the Mentored Undergraduate Summer Experience. She also was principal investigator on an NSF Undergraduate Research and Mentoring in the Biological Sciences (URM) grant, which funded a program of research and mentoring aimed at preparing underrepresented students to pursue a PhD; this program has now been expanded to all science departments at TCNJ. She was a CUR Councilor in the Undergraduate Research Programs Division and currently is a Councilor in the CUR Biology Division. With a PhD in ecology and evolution from Stony Brook University, Morrison has spent more than 25 years conducting plant ecology research solely with undergraduate collaborators, most recently with NSF RUI funding for work on overabundant deer and invasive plants in suburban forests.

Nancy J. Berner earned a PhD at Stanford University, is professor of biology at Sewanee, and holds the William Henderson Chair in biology. She is a former department chair, interim associate dean, and associate provost and currently serves the university as provost. She established Scientific Sewanee, an annual poster session of undergraduate science research, which, as Scholarship Sewanee, has been expanded into a one-day celebration of URSCA across campus. Using funds from a NSF-funded research grant, Berner piloted Research Bridge, an earlycareer research experience for underrepresented students, in her laboratory, which has been expanded to encompass all areas of scientific research through additional external programmatic funding. She has conducted amphibian ecological physiology research with undergraduate collaborators and coauthors for more than 25 years.

Jill M. Manske is a professor of biology at the University of St. Thomas and chair of the Department of Health and Exercise Science. She holds a PhD in immunology and a master's degree in public health. Manske regularly teaches undergraduate courses in immunology, emerging infectious diseases, global health, and women's health. Her research interests include basic science and pedagogy. Her most recent publications have been on maternal influenza vaccination, science and society, and science pedagogy. Manske has served as associate chair of the Department of Biology, chair of the College of Arts and Sciences Faculty, director of the Women's Studies Program, director of the Division of Science and Mathematics, and chair of the Health Professions Advising Committee at UST. She was a member of the Education Committee of the American Association of Immunologists, a visiting research fellow at the University of Minnesota's Center for Infectious Disease Research and Policy, and is an Association of American Colleges and Universities STIRS (Scientific Thinking and Reasoning Skills) Fellow. She served as Councilor in the CUR Biology Division and as a program reviewer for CUR's program review service.

Rebecca M. Jones is an associate professor of chemistry and faculty member of the STEM Accelerator at George Mason University. She received her PhD in inorganic chemistry from the University of Cincinnati in 2004 and then joined the faculty of Austin Peay State University. While earning tenure at APSU, she managed an 
existing internal funding program and Research Forum, which ultimately led to the creation of the Office of Undergraduate Research in 2010. She served as director until January 2012, when she relocated to George Mason to help launch the Office of Student Scholarship Creative Activities and Research (OSCAR). Her programming and assessment work contributed to Mason receiving the CUR Award for Undergraduate Research Accomplishments in 2015. In summer 2015, she transitioned to the College of Science, where she teaches general and inorganic chemistry and pursues research interests such as best practices in STEM education, gender issues in STEM, and the role of the research mentor in undergraduate research experiences.

Shannon N. Davis is associate professor of sociology at George Mason University, where she teaches research methods, sociology of the family, and sociology of gender. She received her $B A$ in sociology from the University of North Carolina at Asheville and her MA and PhD in sociology from North Carolina State University, followed by a postdoctoral fellowship at the University of North
Carolina at Chapel Hill. Davis regularly mentors undergraduate and graduate students in her field and received the OSCAR Mentoring Excellence Award in 2012 in honor of her efforts. Her research interests are focused on understanding the reproduction of gender inequality in institutions, specifically in families and in higher education. Her research has documented how undergraduate research is experienced by students and faculty members, including as an avenue for reducing the leaky pipeline for women and students of color.

Pamela W. Garner is professor of childhood studies in the School of Integrative Studies at George Mason University. She received her doctorate in educational psychology from Texas A\&M University. She completed postdoctoral training in developmental psychology at the University of Houston and the University of Texas Health Science Center. Garner has studied the social emotional development of young children for more than 20 years, and she is a past associate editor for the Early Childhood Research Quarterly. She also is the author of more than 60 articles, published with both undergraduate and graduate students.

\section{Did you know?}

\section{The Council on Undergraduate Research has a Job and Opportunity Board available to members.}

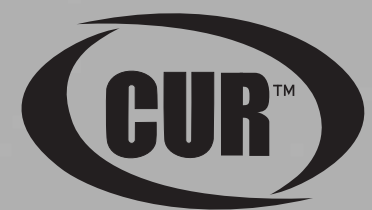

\section{Visit: community.cur.org}

